Abstract 364 Table 1 Showing comparison of baseline parameters in both treatment groups.

\begin{tabular}{|c|c|c|c|c|}
\hline Parameter & \multicolumn{2}{|c|}{ Deflazacort Group (n=31) } & \multicolumn{2}{|c|}{ Prednisolone Group $(n=29)$} \\
\hline Age in years ( mean \pm SD) & \multicolumn{2}{|c|}{$27.3 \pm 9.3$} & \multicolumn{2}{|c|}{$28.3 \pm 7.6$} \\
\hline Sex & \multicolumn{2}{|l|}{ All female } & \multicolumn{2}{|l|}{ All female } \\
\hline $\begin{array}{l}\text { Duration of Steroid Intake before study entry ( } \\
\text { mean in days } \pm S D \text { ) }\end{array}$ & \multicolumn{2}{|l|}{$212.9 \pm 280$} & \multicolumn{2}{|l|}{$124.8 \pm 106.1$} \\
\hline $\begin{array}{l}\text { Steroid dose in before study entry ( mean in } \\
\mathrm{mg} / \text { day } \pm \mathrm{SD} \text { ) }\end{array}$ & \multicolumn{2}{|l|}{$14.3 \pm 20$} & \multicolumn{2}{|l|}{$11.3 \pm 15.9$} \\
\hline \multirow[t]{11}{*}{ Indications for treatment- $n(\%)$} & LN Class II & $1(3.33 \%)$ & LN Class II & $0(0)$ \\
\hline & LN Class III & $1(3.335)$ & LN Class III & $3(10.3 \%)$ \\
\hline & LN Class IV & $12(38.7 \%)$ & LN Class IV & $11(37.9 \%)$ \\
\hline & LN Class V & $3(9.7 \%)$ & LN Class V & $4(13.7 \%)$ \\
\hline & CNS Lupus & $4(12.9 \%)$ & CNS Lupus & $2(6.9 \%)$ \\
\hline & Vasculitis & $4(12.9 \%)$ & Vasculitis & $4(13.7 \%)$ \\
\hline & Cytopenias & $3(9.7 \%)$ & Cytopenias & $3(10.3 \%)$ \\
\hline & $\begin{array}{l}\text { Hemolytic } \\
\text { Anemia }\end{array}$ & $1(3.33 \%)$ & $\begin{array}{l}\text { Hemolytic } \\
\text { Anemia }\end{array}$ & $1(3.5 \%)$ \\
\hline & Myositis & $1(3.33 \%)$ & Myositis & $0(0)$ \\
\hline & ILD & $1(3.33 \%)$ & ILD & $0(0)$ \\
\hline & $\begin{array}{l}\text { Autoimmune } \\
\text { Hepatitis }\end{array}$ & $0(0)$ & $\begin{array}{l}\text { Autoimmun } \\
\text { e Hepatitis }\end{array}$ & $1(3.5 \%)$ \\
\hline
\end{tabular}

Conclusions DFZ and PDN used in comparable manner in SLE had similar efficacy with significantly lesser weight gain, lesser cushingoid features ( including lesser glycaemic elevation) seen in DFZ group.

\section{PROFILE OF HENOCH SCHONLEIN PURPURA (HSP) NEPHRITIS: 23 YEARS EXPERIENCE AT A TERTIARY CARE CENTRE IN NORTH INDIA}

${ }^{1}$ A Gupta*, 'A Kumar, ${ }^{1}$ A Gupta, ${ }^{2} \mathrm{R}$ Nada, ${ }^{3} \mathrm{RW}$ Minz, 'D Suri, ${ }^{1} \mathrm{~A}$ Rawat, ${ }^{1} \mathrm{~S}$ Singh. ${ }^{1} P$ GIMER, Allergy Immunology Unit- Advanced Paediatrics Centre, Chandigarh, India; ${ }^{2} P G I M E R$, Department of Histopathology, Chandigarh, India; ${ }^{3} P G I M E R$, Department of Immunopathology, Chandigarh, India

\subsection{6/lupus-2017-000215.365}

Background and aims Henoch Schonlein Purpura (HSP) is one of the most common vasculitides of childhood. Glomerulonephritis is seen in approximately $30 \%-50 \%$ of the patients and is the principal cause of morbidity and mortality in HSP patients.

Methods 314 children were diagnosed with HSP from 19932015 based on EULAR/PRINTO/PRES criteria. A retrospective case review of all patients with HSP Nephritis (HSPN) was done. HSPN was defined based on urine erythrocyte $>5 / \mathrm{HPF}$ and proteinuria. Patients were divided into four clinical types (Table 1). The severity of renal pathological findings was determined based on the classification of International Study of Kidney Disease (ISKDC), from grades I - VI.
Results Renal involvement was seen in 64 patients after a mean duration of 32.3 days from the onset of symptoms of HSP. Details of patients with HSPN is summarised in table 2, 3 and figure 1. Three fourth of the patients had histological grade II or IIIa (figure 2). $75 \%$ of patients with grade $\geq$ IV had gross hematuria at presentation. Treatment details are shown in figure 3. Patients were followed up for a mean period of 42.9 months during which 13 were lost to follow up and 1 expired. Nephritis resolved in 48 patients (75\%). 13 patients developed renal relapse manifesting as albuminuria with microscopic hematuria in $77 \%$ patients followed by isolated albuminuria (23\%).

Conclusions Renal involvement was noted in $20.4 \%$ of children with HSP. Massive proteinuria was the most common clinical feature. Grade II and IIIa were the most common renal pathological grades.

\section{SPLICING FACTOR PROLINE/GLUTAMINE-RICH (SFPQ) IS A NOVEL AUTOANTIGEN OF ANTI-MDA5 ANTIBODY- POSITIVE DERMATOMYOSITIS/CLINICALLY AMYOPATHIC DERMATOMYOSITIS}

Y Hosono*, R Nakashima, Y Hajime, M Kosaku, O Koichiro, T Mimori. Kyoto university hospital, Clinical immunology and Rheumatology, Kyoto, Japan

\subsection{6/lupus-2017-000215.366}

Background and aims Anti-MDA5-positive dermatomyositis (DM) and clinically amyopathic DM (CADM) often develop 